\title{
EVALUATION OF GREENHOUSE GAS EMISSIONS FROM SOLID WASTE MANAGEMENT PRACTICES IN STATE CAPITALS OF NORTH EASTERN NIGERIA
}

\author{
MSHELIA RICHARD BALTHI ${ }^{*}$ \\ ${ }^{I}$ Department of Mechanical Engineering, Bayero University, Kano, Nigeria
}

\begin{abstract}
Greenhouse gas (GHG) emissions due to solid waste management (SWM) techniques being practiced in the North eastern region of Nigeria are unaccounted for as such these emissions cannot be monitored or controlled. This research estimated GHG emissions into the atmosphere from the current SWM technique practiced in the region, GHG emissions from two different waste management techniques - open burning and incineration was also simulated. The research found that incineration with electricity recovery is the most suitable SWM process therefore suggested that the authorities and other stakeholders in the region should give it serious consideration.
\end{abstract}

Keywords: greenhouse gases, municipal solid waste, solid waste management, waste to energy; carbon footprint

\section{INTRODUCTION}

Generation of Municipal solid waste (MSW) is inextricably linked to daily human activities, this is more pronounced and prevalent in urban areas where most of the day-to-day items used by urban dwellers are bought in disposable bags and other packages which are later discarded. Food wastes are also more common in urban areas which are generally more affluent and can afford to have more than enough food [1,2].

Since the beginning of the industrial age around the middle of the $20^{\text {th }}$ century, there has been a wave of migration of rural dwellers into urban areas primarily seeking employment and a better life. For example, in China alone, about 340 million people migrated from rural to urban areas in the space of just about 30 years [3]. Increase in urban population means an increase in the quantity of MSW being generated and disposed of in these cities. Asides increase in urban population, other factors responsible for increase in MSW generation as found by researchers include: increase in Gross Domestic Product (GDP); increase in family or per capita disposable income; increase in consumption expenditure; levels of education; degree of industrialization; public habits; local climate; age of population; environmental laws/policies and improvement in the standard of living [4-7].

Large quantities of MSW generated in cities have their inherent disposal problems, chief among them is the greenhouse gas (GHG) emissions associated with their disposal. Whether MSW is landfilled, incinerated, openly burned, recycled, or just openly dumped, GHGs are emitted into the atmosphere in the process. Diverse solid waste management (SWM) techniques have been discovered to have varying degrees of impact on the environment carbon footprints [5, 8-10]. According to the IPCC's 2014 report, global GHG emissions from the waste sector have grown steadily and are expected to increase in the forthcoming decades especially in developing countries such as Nigeria because of the dramatic rise in their population and their growing economy [11]. It is estimated

\footnotetext{
* Corresponding author, email: rbmshelia@gmail.com

(C) 2020 Alma Mater Publishing House
} 
that globally, $20 \%$ of emission of GHGs are from solid wastes, that amount is forecasted to reach up to 816 tonnes of carbon dioxide equivalent $\left(\mathrm{tCO}_{2} \mathrm{eq}\right)$ by the end of year 2020 [12].

North-eastern Nigeria which comprises of six states - Adamawa, Bauchi, Borno, Gombe, Taraba and Yobe have in recent years largely been faced with insurgency. The insurgents have perpetually been terrorizing the rural areas in this region thus forcing quite several residents of the rural areas to migrate into state capitals which are largely more secured $[13,14]$. It can be inferred that the increase in the number of residents of the capital cities of these north-eastern states i.e. Bauchi, Damaturu, Gombe, Jalingo, Maiduguri and Yola due to the insurgency induced rural-urban migration has resulted in a sharp rise in the MSW generation rate in these state capitals and thus a consequential increase in GHGs emissions from the waste sector in this region.

Evaluating GHG emissions from the current SWM techniques being practiced in the capital cities of north-eastern Nigeria is essential to the innovation of methods, policy formulation and implementation geared at reducing the GHGs emission from the solid waste sector in this region and the nation at large, hence the need for this research.

\section{EXPERIMENTAL SETUP}

Data for this study was sourced from a wide range of literature, research findings on MSW and SWM in each of the six state capitals were intensively studied so as to obtain the required data for this study. The key information fished out from literature in regard to each of the state capitals are MSW composition, annual MSW generation rate, average moisture content of MSW and SWM techniques being practiced. For uniformity, the MSW generation rate recorded in the year 2017 for each of the state capitals was used for this research.

Using the Institute for Global Environmental Strategies simulation tool for GHGs emission from solid waste management which is a tool based on IPCC's 2006 guidelines for quantification of GHGs from MSW [15], three common waste management scenarios were simulated for each of the state capitals and the corresponding GHGs emission for each scenario obtained. It was gathered from literature that all the six state capitals practice the same SWM technique - open dumping of collected MSW in unmanaged sanitary landfills [16-19], thus open dumping was used as the base scenario. Open burning and incineration with energy (electricity) recovery were used as the second and third simulated scenario respectively. A tailpipe emission analysis methodology was adopted, meaning emissions from other related activities such as collection and transportation of the MSW were not considered. For the incineration scenario, it was assumed that a continuous fluidised bed incinerator was used and that its efficiency is $22 \%$ [20].

\section{RESULTS AND DISCUSSION}

\subsection{Composition and quantities of MSW generated}

It was found that the composition of MSW disposed of at the different sanitary landfills in the state capitals varied widely. Jalingo which experiences the highest average annual rainfall among the six state capitals [21] had the highest percentage of organic waste in the composition of its MSW. Meanwhile, Yola which is the more commerce-oriented state capital in the region unsurprisingly was found to have the highest percentage of plastics. The variation in the composition of the MSW can be said to largely depend on the type of commercial activities in the city and its climatic conditions as corroborated by Khan and Masebinu [22, 23].

For the quantities of MSW disposed of at the sanitary landfills, Gombe which is less populated than Yola and Maiduguri surprisingly ranked first. This however does not mean that Gombe generates more MSW, it rather means the state capital has a better collection efficiency than its contemporaries, this, inference is supported by studies done by other researchers [24, 25]. Damaturu was observed to have the least quantity of MSW disposed at its sanitary landfill, this is not surprising because the city has the least population in the region [26], and as it has been earlier stated, population is a key factor in determining MSW generation. The quantities and composition of MSW disposed of at the sanitary landfills in these cities as found in the literature used for this research are presented in Table 1 and Table 2 respectively [17, 27-34]. 
Table 1. Annual quantities of MSW disposed of at the sanitary landfills in the six state capitals [17, 30-34].

\begin{tabular}{|l|c|}
\hline State Capital & MSW at Dumpsites (Tonnes) \\
\hline Bauchi & 71700 \\
\hline Damaturu & 12736 \\
\hline Gombe & 135871 \\
\hline Jalingo & 19750 \\
\hline State Capital & MSW at Dumpsites (Tonnes) \\
\hline Maiduguri & 61317 \\
\hline Yola & 49447 \\
\hline Total & $\mathbf{3 5 0 8 2 2 . 8 0}$ \\
\hline
\end{tabular}

Table 2. Average weight composition of MSW in the six state capitals [17, 27-29].

\begin{tabular}{|c|c|c|c|c|c|c|}
\hline Category & Bauchi & Damaturu & Gombe & Jalingo & Maiduguri & Yola \\
\hline Food & 5.4 & 6.0 & 9.0 & 5.0 & 6.2 & 6.0 \\
\hline Garden Waste & 18.8 & 27.7 & 13.9 & 29.0 & 18.8 & 6.0 \\
\hline Plastics & 25.0 & 38.2 & 11.4 & 15.0 & 32.6 & 24.0 \\
\hline Paper & 15.0 & 3.6 & 8.2 & 0.0 & 6.7 & 18.0 \\
\hline Textiles & 1.0 & 0.0 & 9.8 & 3.0 & 0.0 & 3.0 \\
\hline Leather/Rubber & 0.0 & 16.6 & 8.3 & 35.0 & 0.0 & 32.0 \\
\hline Glass & 4.9 & 4.2 & 8.9 & 1.0 & 5.6 & 3.0 \\
\hline Metal & 7.8 & 3.6 & 8.3 & 10.0 & 2.9 & 3.0 \\
\hline Hazardous & 0 & 0.0 & 0.0 & 0.0 & 0.0 & 0.0 \\
\hline Others & 22.3 & 0.0 & 22.3 & 2.0 & 27.3 & 5.0 \\
\hline Total & $\mathbf{1 0 0 . 0}$ & $\mathbf{1 0 0 . 0}$ & $\mathbf{1 0 0 . 0}$ & $\mathbf{1 0 0 . 0}$ & $\mathbf{1 0 0 . 0}$ & $\mathbf{1 0 0 . 0}$ \\
\hline
\end{tabular}

\subsection{Greenhouse gas emissions from solid waste management practices}

Open dumping as is being practiced in the region is responsible for emission of GHGs into the atmosphere due to the anaerobic digestion of the organic component of the waste, it was estimated that a total of 5880.95 tonnes of methane annually which translates to 123503.69 tonnes of carbon dioxide equivalent $\left(\mathrm{tCO}_{2} \mathrm{eq}\right)$ is emitted into the atmosphere due to this technique of SWM in the region. Gombe was noted to have the highest emission of GHGs into the atmosphere in the region from its current SWM technique: $50993.79 \mathrm{tCO}_{2} \mathrm{eq}$. Bauchi ranked second with $29419.76 \mathrm{tCO}_{2} \mathrm{eq}$, while Yola, Maiduguri and Damaturu ranked third, fourth and fifth with $17300.78 \mathrm{tCO}_{2} \mathrm{eq}, 16442.70 \mathrm{tCO}_{2} \mathrm{eq}$, and $3852.15 \mathrm{tCO}_{2} \mathrm{eq}$ respectively. When the GHGs emission from this waste management practice is considered through another perspective - emission per tonne of MSW, the picture differs. On emission per tonne of MSW, Bauchi ranks first, Gombe second and Maiduguri least with about 268 $\mathrm{kgCO}_{2}$ eq per tonne of MSW. Figure 1 shows the amount of GHG emitted into the atmosphere per tonne of MSW.

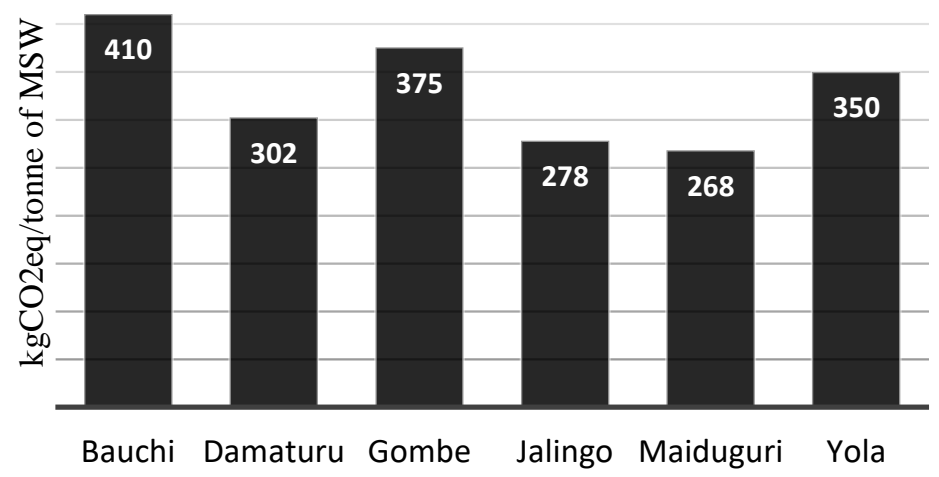

Fig. 1. GHG emission from open dumping per tonne of MSW disposed.

It was found that if the cities being studied are to openly burn their MSW - as is seldom done in some of the dumpsites in these cities [35], a total of $127812.63 \mathrm{tCO}_{2}$ eq will be emitted into the atmosphere. This means the emission of GHGs into the atmosphere if all the MSW in the region are openly burnt will be about $3.4 \%$ higher than the emission emanating from the current MSWM technique in practice. For this scenario, Maiduguri has the 
highest emission, followed by Gombe, Bauchi, Yola, Damaturu and then Jalingo. Meanwhile, Damaturu has the highest GHG emission per tonne of MSW, followed by Maiduguri, Yola Bauchi, Jalingo and then Gombe.

Table 3 shows the amount of GHGs that will be emitted into the atmosphere if open burning of MSW is adopted as the preferred SWM technique in each of the state capitals in North-eastern Nigeria and the corresponding emission per tonne of MSW.

Table 3. GHGs emission from open burning of MSW.

\begin{tabular}{|c|c|c|}
\hline State Capital & tCO2eq & kgCO2eq/tonne of MSW \\
\hline Bauchi & 28655.56 & 399.65 \\
\hline Damaturu & 8267.21 & 649.07 \\
\hline Gombe & 29596.93 & 217.83 \\
\hline Jalingo & 6480.68 & 328.14 \\
\hline Maiduguri & 31844.00 & 519.33 \\
\hline Yola & 22968.24 & 464.51 \\
\hline Total & $\mathbf{1 2 7 8 1 2 . 6 3}$ & $\mathbf{2 5 7 8 . 5 3}$ \\
\hline
\end{tabular}

If incineration with energy (electricity) recovery is considered as the sole MSWM technique in the region, $37042.84 \mathrm{tCO}_{2}$ eq will be emitted into the atmosphere in a year from the 350822.80 tonnes of MSW generated in that year. This is approximately 70\% lower than the emission from open dumping or open burning MSWM techniques. It is pertinent to note that MSW incineration not only reduces the waste to the barest minimum approximately $90 \%$ reduction in mass of waste [36,37], it also reduces the characteristic bad odour associated with open dumping and open burning while equally avoiding the defacing of urban landscape with charred MSW. In addition, the recovery of energy from MSW incineration means reduction (offsetting) of GHGs from conventional fossil fuel, based means of generating electricity. Table 4 shows the gross emissions from incineration of MSW in the various state capitals, the corresponding avoided emission due to the production of electricity in the process and the subsequent net GHGs emission.

Table 4. Gross, avoided, and net GHGs emission from incineration of MSW.

\begin{tabular}{|l|c|c|c|}
\hline State Capital & $\begin{array}{c}\text { Gross Emission } \\
(\mathbf{t C O} \mathbf{2})\end{array}$ & $\begin{array}{c}\text { Avoided Emission } \\
(\mathbf{t C O} \mathbf{2 q})\end{array}$ & $\begin{array}{c}\text { Net Emission } \\
(\mathbf{t C O} \mathbf{2})\end{array}$ \\
\hline Bauchi & 50895.49 & 44497.62 & 6397.88 \\
\hline Damaturu & 14518.31 & 10130.31 & 4388.00 \\
\hline Gombe & 53851.10 & 58031.85 & -4180.75 \\
\hline Jalingo & 11583.75 & 8963.91 & 2619.83 \\
\hline Maiduguri & 56177.02 & 41364.61 & 14812.41 \\
\hline Yola & 40627.40 & 27621.93 & 13005.48 \\
\hline Total & $\mathbf{2 2 7 6 5 3 . 0 6}$ & $\mathbf{1 9 0 6 1 0 . 2 2}$ & $\mathbf{3 7 0 4 2 . 8 4}$ \\
\hline
\end{tabular}

A summary of GHG emissions from the three different MSWM techniques for the entire region is graphically presented in Figures 2 and 3 below. It can be seen from Figure 3 that incineration with energy recovery has the least carbon footprint, while open dumping and open burning have a similar carbon footprint. 


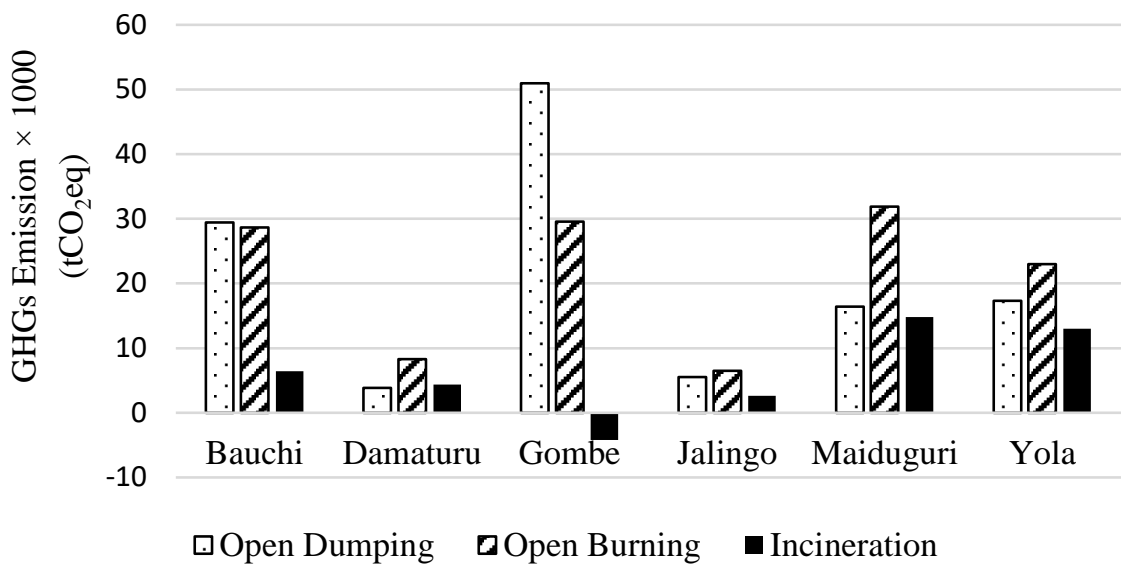

Fig. 2. Summary of GHG emissions showing the share for each state capital.

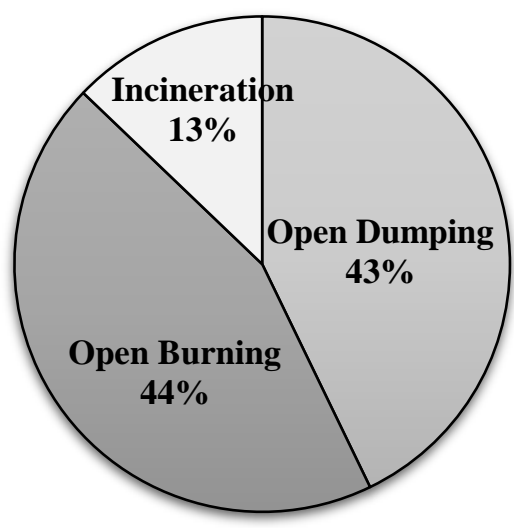

Fig. 3. Summary of GHG emissions ratios for the three SWM techniques.

\section{CONCLUSIONS}

An evaluation of GHG emissions from MSW in the state capitals of the north-eastern region of Nigeria was done. The annual quantity of MSW disposed of at sanitary landfill sites in these cities was determined and then the GHG emissions from three different SWM techniques was simulated. It was found using the that the six state capitals collectively emit $123503.69 \mathrm{tCO}_{2}$ eq from their current SWM technique - open dumping. If, however the SWM technique is changed to open burning, there will be a slight increase of $3.3 \%$ making the collective quantity of GHGs emitted from MSW in the region to be $127812.63 \mathrm{tCO}_{2}$ eq. This implies that open burning is not a suitable alternative to open dumping. The third simulation done showed that if incineration with energy recovery is used as the preferred SWM technique in the region, given the quantities and composition of MSW disposed of at sanitary landfills in the region in the year being reviewed, a total of $37042.84 \mathrm{tCO}_{2}$ eq will be emitted into the atmosphere. This is a reduction of approximately $42 \%$ from the existing SWM technique in practice. Clearly, this is the most environmentally friendly SWM technique and should be given serious consideration by the authorities and relevant stakeholders in the region. Incineration with electricity recovery not only reduces carbon emissions into the atmosphere, it can also serve as a source of income for the states when the $\mathrm{CO}_{2}$ offset from this process is traded in any of the certified emission trading schemes defined in the Kyoto protocol [38]. In addition, this SWM method also provides electricity which can complement what is being supplied to the states from the national grid which happens to be grossly inadequate. 


\section{REFERENCES}

[1] Nguyen, H.H., Heaven, S., Banks, C., Energy potential from the anaerobic digestion of food waste in municipal solid waste stream of urban areas in Vietnam, International Journal of Energy and Environmental Engineering, vol. 5, no. 4, 2014, p. 365-374.

[2] Thyberg, K.L, Tonjes, D.J., Drivers of food waste and their implications for sustainable policy development, Resources, Conservation and Recycling, vol. 106, 2016, p. 110-123.

[3] Tang, Z., The great migration: Rural-urban migration in China and Indonesia, Canadian Studies in Population, vol. 39, no. 3-4, 2012, p. 129-130.

[4] Hoornweg, D., Bhada-Tata, P., What a waste: a global review of solid waste management, Washington DC, 2012.

[5] Liu, J., Li, Q., Gu, W., Wang, C., The Impact of consumption patterns on the generation of municipal solid waste in China: evidences from provincial data, International Journal of Environmental Research and Public Health, vol. i, 2019, p. 1-19.

[6] Intharathirat, R., Salam, P.A., Kumar, S., Untong, A., Forecasting of municipal solid waste quantity in a developing country using multivariate grey models, Waste Management, vol. 39, 2015, p. 3-14.

[7] Mazzanti, M., Zoboli, R., Waste generation, waste disposal and policy effectiveness: evidence on decoupling from the European Union, Resources, Conservation and Recycling, vol. 52, no. 10, 2008, p. 1221-1234.

[8] Ekeuwei, I.T., Azuma, K.I., Ogunmuyiwa, F.B.B., Assessment of environmental impact of solid waste dumpsites using remote sensing, Nigerian Journal of Technology, vol. 37, no. 1, 2018, p. 275-285.

[9] Jia, X., Wang, S., Li, Z., Wang, F., Tan, R.R., Qian, Y., Pinch analysis of GHG mitigation strategies for municipal solid waste management: a case study on Qingdao City, Journal of Cleaner Production, vol. 174, p. 933944,2018

[10] Singh, M., Leena, G., Environmental effects forecasting of GHG emission and linear pinch analysis of municipal solid waste for the city of Faridabad, India, Energy Sources, Part A: Recovery, Utilization, and Environmental Effects, vol. 41, no. 22, 2019, p. 2704-2714.

[11] IPCC, Climate change 2014 mitigation of climate change working group III, Contribution to the Fifth Assessment Report of the Intergovernmental Panel on Climate Change, 2014.

[12] Maria, C., Góis, J., Leitão, A., Challenges and perspectives of greenhouse gases emissions from municipal solid waste management in Angola, Energy Reports, vol. 10, no. 1, 2019, p. 22-25.

[13] Awojobi, O.N., The socio-economic implications of Boko Haram insurgency in the north-east of Nigeria, International Journal of Innovation of Science and Research, vol. 11, no. 1, 2014, p. 144-150.

[14] Adekola, P.O., Migration, urbanisation and environmental problems in Nigeria, Ota, Nigeria: Covenant University Press, 2016.

[15] IPCC, Contribution of working group III to the fourth assessment report of the intergovernmental panel on climate change, Cambridge University Press, 2007.

[16] UNDP-Nigeria, North-East Nigeria waste and debris assessment, Abuja, 2016.

[17] Onuigbo, M.C., Waste to energy, key to solving Nigeria's epileptic power supply: a case study of Gombe Metropolis, Nigeria, The Revitalization of Nigerian Industrial Sector for Rural Infrastructural Development: The Role of Mechanical Engineers, 2018.

[18] Abd'razack, N., Yusuf, A.E., Utange, J.Z., An appraisal of solid waste generation and management in Jalingo City, Nigeria, Environmental Earth Sciences, vol. 3, no. 9, 2013, p. 20-29.

[19] Bogoro, A.G., Appraisal of solid waste collection systems in Bauchi metropolis, Journal of Scientific Research and Studies, vol. 4, no. 12, 2017, p. 373-384.

[20] Daura, L.A., Electricity generation potential of municipal solid waste in Kano Metropolis, Journal of Scientific and Engineering Research, vol. 3, no. 4, 2016, p. 157-161.

[21] Peter, E.E., Precious, E.E., Skill comparison of multiple-linear regression model and artificial neural network model in seasonal rainfall prediction-north east Nigeria, Asian Research Journal of Mathematics, vol. 10, no. 8, 2018, p. 1-10.

[22] Khan, D., Kumar, A., Samadder, S.R., Impact of socioeconomic status on municipal solid waste generation rate, Waste Management, vol. 49, 2016, p. 15-25.

[23] Masebinu, S.O., A review on factors affecting municipal solid waste generation, in 2nd International Engineering Conference, 2017.

[24] Musa, K., Henry, U., Evaluation of the effectiveness and efficiency of house to house inspection manual in the control of sanitation related diseases in Gombe Metropolis, Gombe State, Nigeria, Journal of Environmental Science, Toxicology and Food Technology, vol. 13, no. 1, 2019, p. 5-10.

[25] Jibril, B.A., Adewuyi, T.O, Muhammad, A.B., Abdullahi, S.S., Identification of suitable landfill sites for Kumo urban area Gombe State, Nigeria, FUTY Journal of Environment, vol. 11, no. 1, 2017, p. 1-16. 
[26] National Population Commission, Population distribution by sex, State, LGA and Senetarial District, Abuja, Nigeria, 2010.

[27] Zarma, J.H., Assessment of solid waste disposal system in Jimeta, Adamawa State, Nigeria, British Journal of Environmental Sciences, vol. 7, no. 1, 2018, p. 43-52.

[28] Oumarou, M.B., Shodiya, S., Ngala, G., Aviara, N., Statistical modelling of the energy content of municipal solid wastes in Northern Nigeria, Arid Zone Journal of Engineering, Technology and Environment, vol. 12, 2016, p. 103-109.

[29] Tsunatu, D.Y., Tickson, T.S., Sam, K.D., Namo, J.M., Municipal solid waste as alternative source of energy generation: a case study of Jalingo Metropolis-Taraba State, International Journal of Engineering and Technology, vol. 5, no. 3, 2015, p. 185-193.

[30] Jones, A.N., Alkali, A.N., Evaluating municipal solid waste generation rate and its composition between high and low-income groups in Maiduguri, American Journal of Engineering Research, vol. 8, no. 1, 2019, p. 133-136. [31] Abba, A.H., Inventory of environmental impacts of municipal solid waste in Yola Dumpsites using life cycle analysis, Nigerian Journal of Engineering Science and Technology Research, vol. 5, no. 1, 2019, p. 64-75.

[32] Ogunjuyigbe, A.S.O., Ayodele, T.R., Alao, M.A., Electricity generation from municipal solid waste in some selected cities of Nigeria: an assessment of feasibility, potential and technologies, Renewable and Sustainable Energy Reviews, vol. 80, 2017, p. 149-162.

[33] Oumarou, M.B., Shodiya, S., Ngala, G.M., Bashir, M.A., Artificial neural network modelling of the energy content of municipal solid wastes in northern Nigeria, Arid Zone Journal of Engineering, Technology and Environment, vol. 13, no. 6, 2017, p. 840.

[34] Harir, A.I., Kasim, R., Gana, B.A., Salihu, B.H., The factors influencing municipal solid waste generation in Bauchi town, Nigeria, Advanced Science Letters, vol. 23, no. 9, 2017, p. 9081-9084.

[35] Abba, A.H., Babagana, U.M., Atiku, A.A., Burmamu, B.R., Evaluation of energy potentials from municipal solid waste: a case study, FUTY Journal of Environment, vol. 13, no. 1, 2019, p. 36-45.

[36] Tozlu, A., Özahi, E., Abuşoğlu, A., Waste to energy technologies for municipal solid waste management in Gaziantep, Renewable and Sustainable Energy Reviews, vol. 54, 2016, p. 809-815.

[37] Mian, M.M., Zeng, X., Bin Nasry, A.N., Al-Hamadani, S.M.Z.F., Municipal solid waste management in China: a comparative analysis, Journal of Material Cycles and Waste Management, vol. 19, no. 3, 2017, p. 11271135 .

[38] Lohmann, L., Carbon trading, climate justice and the production of ignorance: ten examples, Development, vol. 51, no. 3, 2008, p. 359-365. 